\title{
Vtelená kognícia, jej filozofické východiská a potenciálny význam pre pedagogiku ${ }^{1}$
}

\section{Zuzana Obertová}

Trnavská univerzita v Trnave, Pedagogická fakulta, Katedra školskej pedagogiky

Redakci zasláno 13. 11. 2012 / upravená verze obdržena 21. 3. 2013 / k uveřejnění přijato 25. 3. 2013

\begin{abstract}
Abstrakt: Cielom príspevku je teoreticky priblížit' teóriu vtelenej kognície, zasadit' ju do širšieho filozofického rámca a uviest' jej potenciálny prínos pre pedagogiku. Príspevok postupuje od ozrejmenia samotného pojmu vtelenie, jeho pôvod vo fenomenológii (M. Merleau-Ponty) i využitie v kultúrnej antropológii (T. J. Csordas). V d'alšej časti sa venujeme filozofickému rámcu, ktorý mal vplyv na teóriu vtelenej kognície a potlačenie dualistického pohl'adu na telo a mysel', ozrejmujeme aspekty vtelenia dotvárajúce obraz vtelenia. V rámci prínosu vtelenej kognície pre súčasnú pedagogiku sa zameriavame na dve oblasti skúmania vtelenej kognície, a to na jazyk a matematiku, ktoré sú považované za prevažne kognitívne a abstraktné koncepty oddelené od tela. Ukázalo sa, že teória vtelenej kognície nedostatočne vysvetluje to, čo vlastne telo je, a o akom tele sa tu pojednáva. Z uvedeného vyplýva, že v oboch uvádzaných oblastiach (jazyk a matematika) je významnou čast'ou najmä skúmanie a význam gest a telesnej skúsenosti pre proces chápania abstraktným systémom a učenia. Zistili sme, že prínos vtelenej kognície pre pedagogiku spočíva v orientácii na telesné konanie, aktivitu a vplyv prostredia a telesnej skúsenosti na kogníciu, ktoré ulahčujú proces učenia.
\end{abstract}

Kl'účové slová: vtelenie, vtelená kognícia, fenomenológia, gestá, matematika, jazyk

Teória vtelenej kognície rozvíjajúca sa od 80-tych rokov 20. storočia prešla určitými zmenami v nazeraní na telo v spojitosti s myslou. Počiatky vtelenej kognície by sme mohli datovat’ publikáciou Lakoffa a Johnsona (1980) Metaphors we live by a knihou Varelu, Tomphosona a Rosch (1991) The embodied mind. Títo autori a mnohí d’alší oživili teóriu o tom, že myslenie je procesom spojeným s naším telom. Od 80-tych rokov sa teória vtelenej kognície, rozvíjajúca sa v rámci kognitívnej vedy rozšírila o poznatky z mnohých iných vedných oblastí, akými sú psychológia, neurológia, biológia, sociológia, filo-

1 Štúdia je výstupom riešenia grantového projektu VEGA 1/0224/11 Archeológia neoliberálnej guvernmentality v súčasnej školskej politike a v teórii vzdelávania, a projektu VEGA1/0091/12 Kultúra performativity a akontability v súčasných vlnách vzdelávacích reforiem. 
zofia. Pôvodná myšlienka vtelenej kognície o telesnej podstate kognitívnych procesov sa v súčasnosti rozvinula na niekol'ko tematických oblastí skúmania. Vznikajú nové poznatky a teórie v jej rámci preukazujúce prepojenie tela, sveta a mysle postupujúc od telesných metafor, cez neverbálnu komunikáciu až k oblasti osvojovania si vedomostí, abstraktných systémov na základe interakcie tela s prostredím.

Cielom tohto príspevku je zasadit’ teóriu vtelenej kognície do širšieho filozofického rámca a ukázat' jej súčasný prínos pre pedagogiku. Vtelená kognícia predstavuje oživenie myšlienky spojenia tela a mysle, nie však tela ako takého, ale tela ktoré reprezentuje interakciu s prostredím, naše konanie a telesné vnímanie. Kognícia vlastná človeku je špecifická najmä tým, že je prepojená s l'udským telom, ktoré má svoje špecifické vlastnosti a danosti, ktoré nemá žiadne iné telo na svete. Preto v nasledujúcom texte uvádzame širší filozofický rámec vtelenej kognície opierajúci sa najmä o fenomenológiu, pričom nemôžeme opomenút' snahu o potlačenie dualistického myslenia - o rozdielnosti tela a duše (mysle).

Súčasným prínosom vtelenej kognície je samotné spojenie tela a mysle, teda aj význam tela $v$ kognitívnych procesoch podstatných $v$ procese učenia sa. Uvádzame niektoré prínosné štúdie a výskumy, ktoré vtelenú kogníciu zasadzujú aj do diskurzu pedagogiky, najmä v oblasti osvojovania si jazyka a matematiky.

Okrem spomenutého uvádzame v príspevku aj osvetlenie pojmu vtelenie, jeho pôvod nadväzujúci na fenomenologické východisko vtelenej kognície a aspekty vtelenia, ktoré nám umožnia bližšie charakterizovat' a pochopit' vtelenú kogníciu. Poukazujeme i na to, že teória vtelenej kognície nemá teoretický základ a vysvetlenie pre socio-kultúrne umiestenie vtelenia.

\section{Vtelenie}

To čo v našom prostredí a jazyku nazývame vtelenie sa v odborných textoch označuje anglickým slovom embodiment. Opačný preklad (z angličtiny do slovenčiny) nám niekol'ko internetových slovníkov ponúka aj možnost' - stelesnenie. Z nášho pohladu je však slovenský pojem vtelenie presnejší, vyjadrujúci to čo Cambridgeský slovník filozofie označuje ako „telesné aspekty l'udskej subjektivity“ (1999, s. 258). Pojem vtelenie je tu spájaný s „európskou fenomenológiou“, najmä s Merleau-Pontym (1966/1974). „Vtelenie nie je 
pojem, ktorý by sa týkal tela ako fyziologickej entity. Týka sa skôr fenomenologického tela a jeho úlohy v našich objektívne zameraných skúsenostiach“ (s. 259).

Vtelenie však nie je len filozofickým pojmom, respektíve neostal rozvíjaný a používaný len vo filozofii a neskôr v kognitívnej vede. 0 fenomenológiu Merleau-Pontyho sa opierajú aj mnohí antropológovia venujúci sa telu, ktorí si tiež „požičali“ pojem vtelenie. Napríklad kultúrny antropológ T.J. Csordas rozvinul pojem vtelenie (1990) a opísal ho na príklade liečitel’ov evanjelického hnutia v Severnej Amerike, ktorí liečili a diagnostikovali svojich „pacientov“ prostredníctvom vlastného tela, vlastného prežívania a skúsenosti na základe príznakov, ktoré popisovali liečení. Csordas rozvinul pojem vtelenie preto, aby upozornil na to, že telo nie je len objekt skúmania, že telo nie je len miestom významov, ale „je existenciálnym základom kultúry“ (s. 5).

Ako sme už uviedli v úvode, počiatky vtelenej kognície smerujú aj od Francisca Varelu a jeho kolegov Evana Thompsona a Eleanor Rosch (1991), pričom spájajú pojem vtelenia s enaktivizmom. Vo svojej knihe The Embodied Mind (vtelená mysel') prepájajú kognitívnu vedu s oblastou ludských skúseností, pričom sa ako väčšina autorov zaoberajúcich sa vtelením či telom opierajú o západnú filozofiu (fenomenológiu Merleau-Pontyho), ale aj o východnú filozofiu (budhizmus, meditácie). Snažia sa poukázat' na to, že kognitívna veda ešte nie je ustálená, opiera sa o mnoho d’alších oblastí (psychológia, psychoanalýza, neurológia, filozofia, antropológia, jazykoveda, umelá inteligencia) a nemôžeme ju v súčasnosti vnímat' len ako vedu o mysli, orientovanú len na mysel' oddelenú od tela a od prostredia. Telo je u Varelu et al. (1991) podobne ako u Merleau-Pontyho podmienkou našej mysle, kognície, bez tela by sme neboli a ani by sme nemysleli. To vyjadruje práve pojem vtelenie, ktorý v zmysle Varelu et al. (s. 238) i Merleau-Pontyho zahŕňa „telo ako prežívanú, skúsenostnú štruktúru, tak aj telo ako kontext alebo milieu kognitívneho mechanizmu“. Podobne ako pojem vtelenie použitý Csordasom, tak aj Varelov pojem enaktivizmus (ang. enactivism) má prekonat' dualitu tela a mysle. Enaktivizmus vyjadruje interakciu mysle so svetom, s prostredím. Enaktivizmus je obdobou pojmu vtelenie, ktorý však v sebe obsahuje aktivitu, pohyb, spojenie myslenia, prostredia a konania.

\subsection{Filozofický kontext vtelenia}

Z nášho pohladu je samotná teória vtelenej kognície zaujímavá práve tým, že prináša nový pohlad na dualistické videnie mysle a tela, môžeme povedat', 
že sa snaží toto dualistické videnie potlačit', možno až prekonat'. Jej zámer vnímat' mysel' ako spojenú s fyzickým telom interagujúcim s prostredím vychádza z fenomenologickej filozofie Merleau-Pontyho, ktorý prisudzoval telu taký význam, aký doteraz nemalo v žiadnej vede. Podobné zamietanie prevažne Descartovho názoru na dualitu mysle a tela vidíme aj v dielach Jána Patočku.

Podla Cheville (2005) mala aj práca Foucaulta vel'ký vplyv na teóriu vtelenej kognície, ktorá „reprezentuje telo zároveň ako objekt kultúry aj ako subjekt kognície“ (s. 86). Foucaultov prínos pre teóriu „vtelenej kognície“ je stručne povedané založený na vplyve priestoru (a rozmiestnenia tiel $\mathrm{v}$ priestore) a na vplyve ideológie, ktoré udávajú vztah tela a mysle, teda tela ako objektu kultúry a zároveň tela, ktoré sa snaží subjektívne vplývat’ na mysel'. „Vtelenie je v každom kultúrnom priestore produktom historizovaných technológií, ktoré sú vryté, dohliadajú a disciplinujú“ (Foucault podl'a Cheville, 2005, s. 91). V nadväznosti na vplyv fyzického priestoru na telá interagujúce s prostredím uvádzame v texte aj prínos kognitívnej lingvistiky (Lakoff \& Johnson, 1980) pre teóriu vtelenej kognície, ktorá uvažuje o vzniku mentálnych schém prostredníctvom telesnej skúsenosti s priestorom.

$\mathrm{V}$ rámci filozofie dochádza v 20. storočí $\mathrm{k}$ rehabilitácii témy tela a telesnosti. Telesnost' však nie je vo filozofii vyhradená určitému myšlienkovému prúdu či smeru. Odkaz na telo a telesnost' vidíme i v analytickej filozofii, ale nepochybne $\mathrm{v}$ tematizovaní tela a telesnosti prispieva najväčšou mierou fenomenológia. „Fenomenológia už v diele svojho zakladatela Edmunda Husserla skúma l'udskú telesnost' ako klúčový fenomén pri pochopení a objasnení povahy našej subjektivity, nášho poznávacieho a skúsenostného vztahu k svetu a nášho medzil'udského spoločenstva" (Urban, 2011, s. 7).

Vtelenie ako centrálny záujem oblasti vtelenej kognície nie je možné z pohladu Descartovho ponímania duality tela a mysle (duše) vysvetlit', preto sa vtelená kognícia, tak ako aj iné oblasti zameriavajúce sa na telo a telesnost' opierajú o fenomenológiu. Fenomenologický prístup k telesnosti sa snaží vyhnút' redukovaniu tela na akýsi fyzický objekt, telo je skôr vnímané ako "prostriedok bytia vo svete“ (Merleau-Ponty, 1966). Merleau-Ponty je významným aj z hladiska prinavracania významu tela vo filozofii ako takej. Dôkazom je jeho kritika Descartovho dualizmu, jeho odopieraniu pozornosti telu a nadrad'ovaní duše. Človeka nie je možné rozdelit' na dušu a telo, pričom duša predstavovala u Descarta podstatu človeka, jeho rozum, jeho myslenie. 
Naopak, l'udia nie sú pre Merleau-Pontyho čistým duchom, ale poznáva ich len „prostredníctvom ich tváre, gesta, slova, skrátka prostredníctvom ich tela" (Merleau-Ponty, 2008, s. 46). Podobne ako Merleau-Ponty i Patočka (1995) sa vyjadruje, že Descartes i antickí filozofi sa pozerajú na telo zvonka. Tento pohl'ad tak prináša telo ako predmet anatómie, fyziológie, všeobecnej biológie a pod. Fenomenológia sa však pozerá na telo ako na „„̌ivé telo“ a „subjektívny fenomén“ (Patočka, 1995, s. 11).

Merleau-Ponty aj Patočka tak akoby preformulovali Descartovo myslím, teda som na som, teda myslím. Preto nie naša mysel' je podmienkou našej existencie, ale naša telesná existencia, telo samotné je podmienkou nášho myslenia. Fenomenológia a jej popredný predstavitel' Merleau-Ponty sú východiskom mnohých textov pojednávajúcich o vtelení a vtelenej kognícii. Niektorí autori (napr. Bautista, Roth, \& Thom, 2012; Nunez, Edwards, \& Matos, 1999; Thom \& Roth, 2011) sa odvolávajú na Merleau-Pontyho a prostredníctvom neho na Husserla, preto sme sa rozhodli tento fenomenologický pohlad na telo a vtelenie stručne doplnit' o prínos českého fenomenológa Jána Patočku. Podl'a neho Husserl síce zdôraznil a „jemne analyzoval“ fenomén subjektívneho tela, ale „zmysel telesného subjektu nie je žiadnym jasným spôsobom uvádzaný do súvislosti s absolútnou reflexiou “" (Patočka, 1995, s. 122). Fenomenológia tak považuje subjektívne telo za podmienku l'udskej existencie, za podmienku života a l'udského prežívania. Aj napriek tomu, že Patočka priamo nenadväzuje na Merleau-Pontyho pojem vtelenia, prináša pohl'ad na živé - subjektívne telo, ktoré tvorí základ všetkého l'udského bytia, interakcie a prežívania. Nehovorí priamo o vtelení, ale zmysel a význam vtelenia nachádzame $v$ jeho prednáškach nepriamo - kritikou objektivizácie tela, vonkajšieho pohl'adu na telo.

\subsection{Aspekty vtelenia}

Prínosom spomínaných autorov a ich kníh je tak vysvetlenie prepojenia tela s kognitívnymi procesmi na základe metafor, avšak ako uvádza Anderson (2003), ani Lakoff a Johnson, tak ako iné texty z oblasti vtelenej kognície nevysvetl'ujú to, čo vlastne telo je. „Aj napriek tomu je možné určit’ štyri aspekty vtelenia, z ktorých každý pomáha stanovit' tvar, hranice a základ vyššieho poznania: fyziológia, evolučná história, praktická aktivita a sociokultúrne umiestnenie..." (Anderson, 2003, s. 105).

2 Patočka hovorí o absolútnej reflexii ako o základe celej filozofie (1995). 
Naša mysel’ „nie je vtelená na základe toho, že všetky jej procesy sú nervovo riadené, ale preto, že jednotlivosti a detaily nášho percepčného a motorického systému hrajú dôležitú úlohu pri koncipovaní definícií a racionálnych úvah" (Anderson, 2003, s. 106). Lakoff a Johnson (1999) sa pritom odvolávajú na Merleau-Pontyho, ktorý tvrdil, že naše zmyslové orgány samy o sebe sú dynamickými nástrojmi skúmania. Tzn., že „bezprostredný výstup vizuálneho systému nie je len statický obraz, ale je sériou senzorických zmien týkajúcich sa oka a hlavy a pohybov objektu (alebo jeho kvality), ktorý vnímame“ (Anderson, 2003, s. 106). Podobne sa fyziológiu videnia zaoberali O'Regan a Noë (2001), ktorí ponúkajú hlbšie vysvetlenie senzomotorického procesu videnia a vizuálneho vedomia. Tvrdia, že „vizuálne vedomie v skutočnosti nevzniká v mozgu! ... Vizuálne vedomie je niečo čo robíme" (O’Regan \& Noë, s. 970). Tak sa autori priblížili enaktivizmu Varelu, Thompsona a Rosch (1991), pretože vizuálne vedomie je v podstate multimodálne, závislé na viacerých zmysloch, na prostredí v ktorom alebo ktoré vnímame a na našej aktivite. Tak má fyziológia vizuálneho systému priamy vplyv na obsah a celkovú štruktúru reprezentácií, ktoré z neho vychádzajú. Fyziológiu vtelenia je dôležité pochopit’ preto, aby sme si uvedomili jej priamy vplyv na naše fyzické obmedzenia pri vnímaní a následne tak pri abstrakciách pojmov, ktoré vyjadrujeme na základe prežitého a vnímaného.

Mysel' je evolučná. „Myslenie vo svojej abstraktnej povahe skôr využíva ako presahuje našu živočíšnu povahu. Zistenie, že myslenie je evolučné úplne mení náš vzt’ah k ostatným živočíchom a mení kompetíciu ludských bytostí na jedinečne racionálnu. Myslenie tak nie je esenciou separovanou od ostatných živočíchov, ale umiestňuje nás do kontinua s nimi“ (Lakoff \& Johnson, 1999, s. 4). Evolučná história našej mysle je vnímaná ako vyvíjajúca sa - teda niektoré pravidlá nášho uvažovania pochádzajú z primitívnejších spôsobov uvažovania. Tzn., že súčasné spôsoby uvažovania a myslenia vychádzajú z jednoduchých percepčných a motorických systémov, na základe ktorých dokážeme abstraktne mysliet'. Znova tak autori poukazujú na telesné prežívanie a vnímanie - ako najjednoduchšie spôsoby myslenia - ktoré tvoria metaforickú bázu vyšších kognitívnych procesov. Kognícia sa tak „analyzuje v evolučnej perspektíve pod označením evolučná epistemológia“ a „celá biologická evolúcia je tak vykladaná ako evolúcia kognície“ (Radnitzky \& Bartley, 1987 podla Kováč, 2006).

Praktická aktivita ohraničuje i naše kognitívne možnosti a opačne. Naša praktická aktivita, telesná skúsenost', ako je aj narábanie s predmetmi, majú 
úzku spojitost' s myslením a s riešením problémov. Príkladom je aj Hutchinsova práca (1995) o distribuovanej kognícii. Poukázal tu na vplyv nástrojov a ich používania, telesnej skúsenosti s nimi na kognitívne štruktúry. Myslenie či vyriešenie určitého problému spočíva na jednej strane $v$ našich kognitívnych schopnostiach a v našich praktických schopnostiach a na druhej strane aj v usporiadaní prostredia. Praktická aktivita determinuje vtelenie kognitívnych procesov spôsobom ako sa na predmety pozeráme, ako s nimi narábame, ako ich umiestňujeme a ako sú umiestňované a pod. K podobným záverom dospeli aj Susi, Lindblom a Ziemke (2003) či Kirsch a Maglio (1994), ktorí sú zástancami Hutchinsovej distribuovanej kognície a zdôrazňujú význam používania nástrojov (najmä v oblasti práce s počítačmi) a prostredia pre riešenie problémov a samotné myslenie.

Ako posledný aspekt vtelenia uvádza Anderson (2003) socio-kultúrne umiestnenie. Ako sám uvažuje, „praktická aktivita a interakcia s prostredím sú samé o sebe kognitívnymi stratégiami... a najmä u l'udí sú tieto interakcie umiestnené v širšom sociálnom a kultúrnom kontexte" (s.109), avšak tieto aspekty v knihe Lakoffa a Johnsona (1999) sú rozoberané v niekol'kých kapitolách „povýšeneckým tónom a nedbalým myslením, ktoré často charakterizujú tieto kapitoly" (Anderson, 2003, s. 110).

Akési rozuzlenie tohto problému socio-kultúrneho umiestnenia vidíme v tom, že vtelená kognícia a aj samotná teória konceptuálnej metafory nemajú zázemie v sociálnej a kultúrnej antropológii, o ktoré sa opiera napríklad školská etnografia (pozri Kaščák \& Obertová, 2012) tela zaoberajúca sa taktiež fyzickým ukotvením kognitívnych procesov v sociálnom a kultúrnom prostredí školy, ktoré je samo o sebe špecifické.

\section{Fyzické ukotvenie kognitívnych procesov}

Kognitívna veda dlho považovala mysel' za „procesor abstraktných informácií, ktorej spojitost' s vonkajším svetom mala len malý význam" (Wilson, 2002, s. 625), avšak vtelená kognícia prináša nový pohl’ad na mysel', ktorá je vždy spojená s vonkajším prostredím, a to prostredníctvom nášho tela. Dá sa tak povedat', že sme vo svete „fyzicky ukotvení" a to nie len pre to, že telo je akousi fyzickou a biologickou entitou, ale má aj svoje kultúrne, sociálne, politické a psychologické aspekty vplývajúce na iných a podporujúce naše kognitívne procesy. 
Významným príspevkom takéhoto „fyzického ukotvenia“ našich kognitívnych procesov je kniha Metafory, kterými žijeme od Lakoffa a Johnsona (1980, český preklad - 2002). Ich teória konceptuálnej metafory tvorí akýsi most medzi telesnými procesmi a abstraktnými pojmami. Podla nich sa ani pri vyjadrovaní či pochopení abstraktných pojmov nezaobídeme bez tela a bez telesnej skúsenosti. Autori v knihe prezentujú analýzy metafor používaných v bežnej reči ako dôkaz toho, že metafora je globálnym aspektom myslenia. Ich konceptuálna metafora je chápaná ako spôsob, ktorým myslíme - nenapíňajú tak lingvistickú definíciu metafory. Všeobecne autori vychádzajú z toho, že prevažná čast' nášho pojmového systému je štruktúrovaná metaforicky, čiže „väčšine pojmov rozumieme čiastočne na základe iných pojmov“ (Lakoff \& Johnson, 2002, s. 74). Sú však aj pojmy, ktorým rozumieme priamo bez metafory. Podla autorov sú to najmä pojmy, „ktoré sa rodia z našej priestorovej skúsenosti“ (ibid.), teda z našej interakcie s fyzickým prostredím. Takýto metaforický orientačný pojem uvedieme neskôr na príklade cudzojazyčného vzdelávania v materských školách.

Aby sme zostali pri autoroch Lakoffa a Johnsona, zhrnieme ich pozitívny prínos na teóriu vtelenej kognície, a teda aj pre školskú etnografiu tela, ktorú vidíme aj v knihe Philosophy in the flesh (1999). Autori uvádzajú metaforické mapovanie „ciele sú destinácie“ (ang. purposes are destinations), ktoré vyjadruje telesnú podmienenost' kognitívnych operácií, napr. plánovania. Ako ciel' či ciele všeobecne si predstavujeme nejaké miesto. Spracovávanie procesu plánovania dosiahnutia ciela myšlienkovo prepájame sa našou telesnou - priestorovou skúsenost'ou. Jedná sa tu znova o priestorovú orientáciu človeka (dopredu/dozadu, hore/dole, dnu/do/von/z a pod.), ktorá je spojená $\mathrm{s}$ našou telesnou orientáciou a fyzickým pohybom tela. Preto si nami stanovený ciel' predstavíme ako miesto pred nami, ktoré musíme dosiahnut', ku ktorému musíme príst', prekonat' prekážky, naplánovat' si túto cestu a pod.

Obe spomínané knihy v podstate hovoria o tom, že l'udia používajú metafory na to, aby dokázali vysvetlit’ okolitý svet, ktorému porozumejú na základe telesnej skúsenosti. Tak svet okolo nás ako aj náš vnútorný svet dokážeme vysvetlit’ na základe telesne prežívaného, ktoré vytvára akýsi telesný kognitívny koncept. Z tohto konceptu sa odvíjajú d’alšie koncepty vznikajúce „zmiešavaním“ doteraz vytvorených konceptov. 0 takomto koncepčnom zmiešavaní hovoria Fauconnier a Turner (2002), opierajúci sa o teóriu konceptuálnej metafory Lakoffa a Johnsona. 
Iní autori hovoria o fyzickom ukotvení, teda o úlohe tela v kognícii prostredníctvom symbolických prístupov v myslení a hovorení, akými je používanie gest v komunikácii (Alibali, 2005; Arzarello \& Edwards, 2005; Goldin-Meadow et al., 2009; Hostetter \& Alibali, 2008; Roth, 2001; Wagner et al., 2004). L'udia často používajú gestikuláciu nie len spontánne, ale aj na opisovanie vnútorných, mentálnych obrazov, často používajú gestá aj pri vyjadrovaní priestorových či pohybových informácií. Ako príklad uvádzajú Hostetter a Alibali (2008, s. 500) hovorcu udávajúceho pokyn „držte sa vlavo“, ktorý počas prehovoru posúva svoju ruku dolava. Tento pohyb využíva priestor a činnost' na vyjadrenie priestorového konceptu vl'avo, ktorý je pravdepodobne prezentovaný v hovorcovom mentálnom obraze. Gestá a ich rôzne podoby sú ústredným rysom aj v procese učenia ( $\mathrm{sa}$ ) v školách, v kognitívnych procesoch, v chápaní abstraktným pojmom a situáciám, nie len $v$ komunikácii. Na tento fakt i na to, že je nedostatok výskumov venujúcich sa významu gest v školskom prostredí poukázal Roth (2001, s. 365): „Tých niekol'ko málo existujúcich štúdií zameriavajúcich sa na význam gest vo vzdelávacom kontexte sa objavili v časopisoch, ktoré sa primárne nezameriavajú na pedagogický výskum a naznačujú, že takýto výskum by mohol mat' obrovský význam a pomohol by pochopit' význam gest $\mathrm{v}$ poznávaní a v učení sa prírodovedným predmetom." Takýmto do školy situovaným výskumom je napr. kniha Marka Knappa a Judith Hall (2006), v ktorej opísali niekol'ko spôsobov ako neverbálne správy interagujú so slovami, teda s verbálnymi správami v triede. Príkladom čisto neverbálnej komunikácie je napr., ked' učitel'ka cudzích jazykov dáva palec hore ako signál pre študenta, aby použil správny slovesný čas. Takéto gesto pomáha žiakovi aby napravil chybu bez akéhokol'vek verbálneho zásahu - znamená to, že učitel' tak nemusí prerušovat' výpoved’ žiaka. Neverbálne správy tiež regulujú konverzačný tok, napr. ked' učitel' kýva hlavou počas odpovedania žiaka, aby ho podporil v d'alšom hovorení. Ale verbálne a neverbálne správy môžu byt' samozrejme aj v rozpore (ako to naznačuje v prehladoch výskumov aj Roth, 2001), napr. ak žiak povie svojej učitel'ke: „Milujem gramatiku, pani učitel'ka!", ale jeho hlas vedie učitel'ku k presvedčeniu, že je to posledná vec na svete, ktorá ho zaujíma.

Neverbálna komunikácia a samotný výskum gest je tak silne orientovaný i v pedagogickom diskurze na komunikáciu, vyučovanie jazyka, inštruovanie študentov alebo žiakov a pod. Vo vyučovaní a učení matematiky a prírodných vied sa mnoho učitel'ov zameriava na písaný a hovorený jazyk, ktoré sú výsledkom vyučovania a učenia sa. Roth (2009) však považuje pozna- 
nie osvojené prostredníctvom stelesnenej akcie, ktorá sa neustále vynára z interaktívneho výukového prostredia za významné. Skúma myšlienku, že matematická reprezentácia tvorí rozhranie medzi stelesnenými a kultúrnymi aspektmi poznania a učenia matematiky. Bližšie sa však budeme venovat' gestám na vyučovaní matematiky v 4. časti príspevku.

Teória vtelenej kognície tak vyjadruje fyzické ukotvenie kognitívnych procesov najmä prostredníctvom existencie tela, ktoré je zasadené do fyzického prostredia, ktoré naň pôsobí a telo ho subjektívne vníma (tu je pomerne viditel'ný vplyv Foucaultovej teórie o vplyve priestoru na telo). Preto aj naše verbálne (metaforické) či neverbálne (gestá) vyjadrenia a mentálne obrazy majú svoju podstatu v priestore a v pohybe. Stále častejšie sa stretávame s výskumami a príspevkami venujúcimi sa gestám, neverbálnej komunikácii a vteleniu v oblasti vyučovania a učenia sa, ktoré sú nepochybne spojené s kogníciou.

\section{$3 \quad$ Vtelený jazyk}

Vyššie spomenuté aspekty vtelenia vidíme v priestorových pojmoch Lakoffa a Johnsona (2002). Fyziológia vtelenia, evolučná história, praktická aktivita a socio-kultúrne umiestnenie charakterizujú priestorové pojmy, ktoré sú v našich mysliach vtelené. Tieto ich aspekty možno vidiet' už na skôr zmieňovanom osvojovaní si cudzieho jazyka. Autori tvrdia, že existuje „korešpondencia medzi našimi emóciami (ako je štastie) a zmyslovo-motorickými skúsenost’ami (ako je vzpriamené držanie tela), a to tvorí bázu pre orientačné metaforické pojmy (ako štastný je hore)“ (Lakoff \& Johnson, 2002, s. 76). Podobne sme tento aspekt pozorovali na videozáznamoch vyučovania nemeckého jazyka $v$ materskej škole. Orientačný metaforický pojem, ktorý sme identifikovali je: dobré je hore, zlé je dole. Spojitost' kognitívnych štruktúr detí je viditel'ná na ich telesnom prejave - jednoduchom geste. Ak sa ich lektorka opýtala, ako sa dnes majú, deti ukazovali palec hore (gut - dobre) a palec dole (schlecht - zle). Na základe určitých telesných skúseností tak dokážeme prepojit' naše pocity s polohou tela. Takýto orientačný metaforický pojem, ktorý si deti na základe telesnej skúsenosti vybudovali v materinskom jazyku je „nástrojom“ osvojenia si pojmov i v cudzom jazyku. Bázu zapamätania si a následného osvojenia pojmov v cudzom jazyku (gut a schlecht) tak pravdepodobne tvorí ich telesná skúsenost', ktorej porozumeli už v materinskom jazyku. Preto sa cudzie slovo gut spája s gestom palec hore, má teda urči- 
té symbolické (telesné) vyjadrenie, ktoré však môže byt' aj kultúrne kódované. Jedná sa o rozvinutie už vzniknutej kognitívnej štruktúry - orientačného pojmu - o dimenziu cudzieho jazyka. Teda performácia tohto gesta (napr. palec hore) vyvoláva verbálne vyjadrenie v cudzom jazyku (gut). Podobne sa vyjadrujú aj Kaščák a Pupala (2011, s. 95), že „akákolvek telesná performácia má jazykovú podobu, pretože symbolizuje“. V tomto prípade môžeme predpokladat', že tak jednoduché gesto ako je „palec hore“ vychádza z určitej kultúrnej podmienenosti, no z hl'adiska vtelenej kognície by sme mohli povedat', že ak dôjde k prepojeniu tohto gesta - telesného konceptu - so slovným vyjadrením - verbálnym konceptom, vytvorí sa akýsi nový koncept spájajúci telo a slovný výraz. Ak tento koncept doplníme o pojem v cudzom jazyku, vznikne nová štruktúra založená primárne na telesnej skúsenosti - na orientačnom pojme dobré je hore. Z hladiska osvojovania si cudzieho jazyka záleží často aj na pamäti žiakov/detí, podl'a teórie vtelenej kognície (i konceptuálnej metafory) je l'ahšie zapamätat' si význam alebo výraz na základe priestorovej reprezentácie. Teda ak je tento pojem spojený s určitou priestorovou skúsenost'ou je jednoduchšie sa na jeho význam rozpamätat'.

Príspevok Nguyena Tat Thanga (2009) z oblasti kognitívnej lingvistiky sa opiera taktiež o centrálnu tézu „vtelenia jazyka“. Autor sa vyjadruje o význame jazyka pre komunikáciu, ktorý nikdy nie je oddelený od našej telesnej alebo prežitej skúsenosti. Takéto vyjadrenie je možné podporit' faktom, že i malé deti poznávajú svet okolo seba najmä prostredníctvom svojho tela, prostredníctvom vnímania, a preto nedokážu neskôr vyjadrit' niečo, čo nezažili, neskúsili, nevideli, nedržali a pod. Podobne sa vyjadrujú aj Hostetter a Hopkins (2002), ktorí tvrdia že l'udia pri rozprávaní používajú gestá a telesné pohyby počas hovorenia viac, ak prerozprávajú príbeh, ktorý videli ako by len čítali o tomto príbehu. Znamená to, že l'udia, ktorí tento príbeh videli sa pri jeho prerozprávaní opierajú o bohatšie priestorové reprezentácie ako l'udia, ktorí len o príbehu čítali. Samotný jazyk i gestá tak vychádzajú najmä z prežitého, vteleného mentálneho obrazu.

Thang (2009) poukazuje tiež na používanie určitých jazykových metafor spojených s telom, čím nadväzuje na teóriu Lakoffa a Johnsona (2002). Bez pochopenia týchto metafor nie je možné osvojit' si cudzí jazyk. Ako príklad uvádza výrazy v angličtine: „ručičky hodín (hands of clock), ústie rieky (the mounth of a river), úpätie hory (foot of a hill)" (Thang, 2009, s. 252). V každom jazyku tak existuje vel'ké množstvo telesných konceptov používaných v rôznych metaforických vyjadreniach, kde samotná telesná skúsenost' 
hrá významnú úlohu nie len vo vyjadrovaní myšlienok, ale aj v pochopení toho čo čítame či počujeme.

Výskum podporujúci úlohu vtelenia pri osvojovaní si jazyka predstavuje aj Maouene et al. (2011) venujúci sa úlohe telesnej skúsenosti pri ranom osvojovaní si slovies. Zo zoznamu približne stovky konkrétnych a abstraktných slovies ${ }^{3}$, ktoré sú $\mathrm{v}$ ranej slovnej zásobe detí, zadávali autori tieto slovesá dospelým - študentom, ktorí určovali čast' tela asociujúcu sa $\mathrm{s}$ daným slovesom. Najčastejšie boli tieto slovesá spájané s očami, ušami, ústami, nohami a rukami. Autori zistili, že „asociácia slovies s jednou určitou častou tela môže byt' lepším prediktorom osvojenia si raných slovies ako je konkrétna či abstraktná povaha slovies“ (ibid., s. 473). K podobným zisteniam dospeli aj Kaščák a Pupala (2011) poukazujúci na iniciálnu výučbu cudzieho jazyka, najmä v téme „Moje telo“ (nem. mein Körper), ktorá sa opierala najmä o slovnú zásobu podstatných mien v nemeckom jazyku.

Výskumy hovoriace o vtelení jazyka sa teda opierajú o to, že jazyk nie je oddelený od percepcie a akcie. Porozumenie jazyku, konkrétnym slovám a vetám je vtelené, previazané s vnímaním a konaním, čo preukazujú aj výsledky Glenberga a Kaschaka (2002) či Zwaana a Taylora (2006), ktorí sa venujú porozumeniu viet na základe reakčného času stlačenia či otočenia tlačidla podl'a toho v akom smere bola tzv. „prenosová veta ${ }^{4 “}$ čítaná. Napr. Glenberg a Kaschak (2002) dávali participantom čítat' tieto prenosové vety a určovat' či majú alebo nemajú význam prostredníctvom tlačidla, ktoré bolo bližšie alebo d’alej od tela participanta. Spomenutí autori zistili, že reakčný čas participantov na zmysluplnost' a teda aj pochopenie významu vety bol kratší, ak sa smer vety zhodoval so smerom (blízkostou) tlačidla. Uvedenú schému porozumenia jazyku nazvali autori efekt kompatibility akcie a vety (actionsentence compatibility effect, ACE).

Porozumenie jazyku, ktorý je abstraktným systémom, je teda rovnako previazané s telesnou skúsenostou a s našim konaním. Uvedené štúdie sú rozpracované najmä z pohladu psychológie a kognitívnej lingvistiky (najmä v oblasti metafor), avšak opierajú sa aj o neurovedu (napr. aktivizácia moto-

\footnotetext{
Tento zoznam slovies vychádza zo štúdie Fensona et al. (1994), obsahuje 102 slovies, ktoré sa nachádzajú v aktívnej zásobe minimálne 50\% skúmaných (amerických) detí vo veku 30 mesiacov.

4 Prenosová veta je tu chápaná ako veta vypovedajúca o pohybe smerom k telu (napr. Jana mi podala knihu.) alebo od tela (Ja som podala knihu Jane.), pričom táto veta môže byt' zmysluplná (Jana mi podala knihu.) alebo nezmysluplná (Jana mi zasvietila knihu.).
} 
rického centra v mozgu nie len pri vykonávaní či predstavovaní si aktivity, ale aj pri hovorení či čítaní; Pulvermuller, 2005). Pre pedagogiku je relevantný význam gest v komunikácii (podobne ako v matematike), ktoré podporujú priestorovú predstavivost' žiakov spájajúcu sa s lahším pochopením inštrukcie alebo významu vety. Príkladom je vyššie uvedený ACE efekt Glenberga a Kaschaka (2002), ktorý sa venuje v školstve vel'mi rozšírenej problematike spojenej s testovaním žiakov, a to slabej úrovni žiakov v čítaní s porozumením. Vtelená kognícia a jej empirické preskúmavanie problematiky jazyka (používania či porozumenia) by mohli v budúcnosti viest' $\mathrm{k}$ vytvoreniu didaktických postupov založených na vtelení jazyka, ktoré by viedli k zlepšieniu jazykových a čitatel'ských kompetencií žiakov.

\section{Matematika v tele}

Podobne ako teória vtelenia jazyka, existuje aj niekol'ko výskumov venujúcich sa vteleniu matematiky (Arzarello \& Edwards, 2005; Bautista et al., 2012; Goldin-Meadow et al., 2009; Lakoff \& Nunez, 2000; Wagner Cook, 2011) alebo skôr matematických konceptov, ktoré sú všeobecne považované za vel'mi abstraktné. Všetky tieto výskumy sú orientované na význam a potrebu pohybov a gest pre matematické myslenie. Sú to gestá, ktoré vznikajú počas rozhovoru o matematických konceptoch, objektoch či na vyučovaní matematiky i bez verbálnych prejavov a značne vplývajú na zmenu matematického zmýšl'ania detí i dospelých, čo podporuje tvrdenie že matematické reprezentácie sú vtelené. Roth (2009) považuje poznanie osvojené prostredníctvom vtelenej akcie, ktorá sa neustále vynára $\mathrm{z}$ interaktívneho výukového prostredia za významné. Skúma myšlienku, že matematická reprezentácia tvorí rozhranie medzi vtelenými a kultúrnymi aspektmi poznania a učenia matematiky.

Oblast' matematického učenia (sa), ktorá zdôrazňuje práve význam tela má podobne ako vtelenie jazyka pomerne obšírnu bázu teoretických i experimentálnych výskumov a oblastí, akými sú podla Arzarello a Edwardsa (2005) neurológia, kognitívna veda, experimentálna psychológia, semiotika, lingvistika a samozrejme filozofia. Takáto široká teoretická báza ponúka pole na preskúmanie interakcií medzi jazykom, gestom, telesnou aktivitou, znakmi a symbolmi v učení a vyučovaní matematiky.

Istotne najvplyvnejšou knihou $\mathrm{v}$ oblasti teórie vtelenia matematiky bola kniha Lakoffa a Núñeza (2000) Where Mathematics comes from, v ktorej autori tvrdia, že matematické koncepty sú podporované vizuálnymi a motorickými 
reprezentáciami. Teória vtelenej kognície bola autormi však aplikovaná nie na samotnú matematiku, ale na jazyk, ktorým opisujeme a vysvetlujeme matematické koncepty. Znova sa vraciame k vtelenému jazyku a metaforám či metaforickým pojmom, ktoré vychádzajú z našich telesných skúseností.

Tak ako aj metaforický jazyk, tak aj gestá sú používané počas matematického myslenia, príkladom je najjednoduchšie počítanie, pri ktorom používame spontánne ukazovacie gesto - ukazovanie na prstoch, ktoré vyjadruje súbor spočítaných objektov. Počítanie na prstoch je tak pohybom, lepšie povedané vizualizáciou matematického konceptu. Prsty ruky tak pre deti predstavujú určitý symbolický systém, kde jeden prst predstavuje určité množstvo (najčastejšie jeden) a urýchlujú tak vyrátanie jednoduchého matematického príkladu (často v prvom ročníku základnej školy, príklady do desat'). Počítanie na prstoch u detí na základnej škole ul'ahčuje pochopenie abstraktného matematického systému, ktorý je možné v určitom obmedzení (len do desat') vizualizovat' vystieraním prstov (pridávaním v príkladoch na sčítanie) a skrčením prstov (odoberaním v príkladoch na odčítanie).

V úvode tejto podkapitoly sme uviedli výskumy venujúce sa vteleniu matematického myslenia, ktoré vo svojej podstate dokazujú, že používanie gest na vyučovaní matematiky zlepšuje učenie, no tieto výskumy nedokladujú spôsob ako samotné gestá zlepšujú učenie matematiky. Preto sa niektoré výskumy vybrali experimentálnym smerom, najmä na prvom stupni základnej školy, kedy ovplyvňovali výučbu matematiky práve pomocou gest, ako je to aj v prípade Goldin-Meadow et al. (2009). Autori výskumu v niekol'kých skupinách ovplyvňovali samotnú výučbu tým, že na vysvetlovanie používali gestá, alebo ich počas výučby ignorovali, a taktiež žiakov inštruovali, aby vysvetlili matematický problém bud' s použitím gest alebo bez nich. Zistili, že žiaci lepšie pochopia a vysvetlia problém ak počas toho používajú gestá. Pohyby tela a samotné gestá (ukazovanie na konkrétne číslice na tabuli v príklade) tak podl'a autorov pomáhajú žiakom zamerat' svoju pozornost' na čísla (tie čísla, na ktoré ukazoval už učitel' počas vysvetl'ovania ako riešit' daný problém alebo príklad), s ktorými majú počas riešenia problému manipulovat'. Tento fakt vychádza aj z neurologicky orientovaného výskumu Pulvermullera (2005), ktorý poukazoval na to, že pri hovorení slovies, ktoré vyjadrujú určitú aktivitu a spájajú sa s konkrétnou častou tela (podobne aj Maouene et al., 2011) sa aktivuje i tá čast’ mozgu, ktorá je aktívna pri vykonávaní pohybu (napr. pri slovese kopnút'). Podobne to môže byt' nie len so slovesami, ale i s podstat- 
nými menami alebo pri riešení matematického príkladu s pomocou gest, pričom pri riešení príkladu sa aktivuje i čast' mozgu zodpovedná za používanie gest, čo vedie k riešeniu s väčšou aktivitou mozgu.

Učitelia učiaci matematiku na prvom stupni používajú gestá ovel’a viac ako iné neverbálne prejavy alebo materiály, akými sú napríklad geometrické pomôcky (Flevares \& Perry, 2001). Gestá ako telesná zložka na vyučovaní pomáhajú porozumiet' inštrukciám aj v predmetoch ako je matematika a fyzika. Kelly (2001) dokonca tvrdí, že už deti predškolského veku porozumejú významu inštrukcie ovela lepšie, ked' je verbálny prejav spojený s gestom, ako samotnému verbálnemu prejavu alebo gestu. Rovnako sa vyjadruje aj Perry et al. (1995), ktorý tvrdí, že ked' sa det'om prezentovali inštrukcie o matematickej rovnosti, porozumeli im lepšie, ak boli spojené s gestami.

Výskum Pinga a Goldin-Meadow (2006) sa snažil dokázat', že deti sa naučia z gest aj vtedy, ak objekty, na ktoré sa gestá vztahujú, nie sú viditel'né. Deti dostávali inštrukcie len verbálne a neskôr verbálne $\mathrm{v}$ spojení s gestami. Participantmi boli deti prvého stupňa a výskum bol zameraný na veličiny ako je dížka, počet a objem. Ping a Goldin-Meadow (2006) potvrdili, že gestá nie sú len spojením hovoreného slova s viditel'ným objektom, ale k porozumeniu inštrukcie dôjde aj v prípade, že inštrukcia spojená s gestom sa vztahuje na neviditel'ný objekt. Teda používanie gest alebo telesná aktivita, konanie môžu mat' vplyv aj na pochopenie abstraktných a neviditel'ných pojmov a situácií.

Avšak nie všetky gestá a pohyby používané spontánne pri vysvetlovaní (aj matematických) riešení musia byt' priamo spojené s pochopením. Samotné gestá používané učitelom pri vysvetlovaní však preukázatel'ne pomáhajú žiakom (ktorí gesto zopakujú pri riešení) rozpamätat' sa na riešenie matematického problému a zmenit' ich uvažovanie o probléme (Goldin-Meadow et al., 2009; Ping \& Goldin-Meadow, 2006; Wagner Cook, 2011). Predpokladáme, že podobne ako pri osvojovaní si cudzieho jazyka, tak aj pri riešení matematických problémov nejaký telesný pohyb, konanie alebo gesto vytvárajú koncept spojený so samotnou vedomostou (s pojmom v cudzom jazyku či s postupom riešenia príkladu), ktorú si žiaci lahšie osvoja ak je primárne založená na telesnej skúsenosti.

Prínosom výskumov a teoretických úvah vtelenej kognície v oblasti matematiky (často aj fyziky) je v týchto štúdiách prínos samotných gest. Žiakom sa často sprostredkovávajú hotové výsledky i postupy riešenia problémov (príkladov), ktoré je zložité si zapamätat'. Ak si žiaci spoja postup riešenia 
s gestom alebo gestami, pohybmi, dochádza k zapojeniu väčšej časti mozgu, k mnohým nervovým prepojeniam, ktoré vedú $\mathrm{k}$ tomu, že žiak sa rýchlejšie rozpamätá na postup riešenia. Taktiež gestá učitelov pri vysvetlovaní i pri inštrukciách pomáhajú žiakom pochopit’ predávanú informáciu. Preto je možno potrebné aj v tak kognitívne orientovanej oblasti akou je matematika dbat' na to, aby žiaci používali gestá, aby pri riešení využívali aj drobné telesné pohyby, konanie, ukazovanie a pod., ktoré im pomôžu pri samostatnom matematickom zmýšlaní predstavit' si abstraktný koncept ovel'a l’ahšie, ak je spojený s činnostou.

\section{Záver}

V tomto príspevku sme sa snažili stručne zasadit' problematiku vtelenej kognície alebo vtelenej mysle do širšieho filozofického kontextu. Tento kontext je značne ovplyvnený fenomenológiou, z ktorej vychádza aj samotný pojem vtelenie. Okrem fenomenológie však uvádzame aj postreh Cheville (2005), ktorá pokladá za prínosný aj Foucaultov koncept tela pre teóriu vtelenej kognície. V súvislosti s fenomenológiou, ktorá sa snaží prekonat' dualitu tela a mysle sme ozrejmili pôvod pojmu vtelenie, ktorý síce pochádza od Merleau-Pontyho, ale rozvíja sa aj v sociálnej a kultúrnej antropológii (Csordas, 1990) a neskôr sa koncept vtelenia premieta do kognitívnej vedy, najmä do kognitívnej lingvistiky v téze vtelenia jazyka. Aj z tohto dôvodu sme uviedli niekol'ko aspektov vtelenia (vychádzajúc z Andersona, 2003), ktoré dopĺnajú celkový obraz vtelenia. $V$ tomto bode uvádzame, že k aspektom vtelenia patrí aj socio-kultúrne umiestnenie, ktoré nie je dostatočne ozrejmené $\mathrm{v}$ teórii vtelenej kognície. Preto tento aspekt vtelenia považujeme za dostatočne ozrejmený v príspevku o školskej etnografii tela (Kaščák \& Obertová, 2012), ktorý sa zameriava aj na východiská školskej etnografie tela prevažne zakorenené v sociálnej a kultúrnej antropológii (napr. aj Csordas, 1990).

Všeobecnou otázkou vyplývajúcou z tohto textu je však otázka 0 akom tele sa v spomenutých štúdiách vlastne hovorí? Vyplývajúc z filozofického zázemia vtelenej kognície by sa dalo povedat', že sa jedná najmä o subjektívne fenomenologické telo, avšak mnohé texty vtelenej kognície sa opierajú o neurovedu či biológiu, preto získavame dojem, že nejde len o fenomenologické telo, ale aj o telo biologické.

Často sa autori vyjadrujú o telesných skúsenostiach, o vplyve prostredia na osvojovanie si vedomostí, jazyka a matematiky. Na jednej strane sa spomenuté 
štúdie zameriavajú aj na telesné vnímanie fenomenologického tela, na druhej strane sa však venujú aj interakcii biologického tela s prostredím a na jeho vplyv na kognitívne procesy. Aj u inšpiratívnych autorov Lakoffa a Johnsona (1999, 2002) a ich konceptuálnej metafory vidíme nejednoznačnost' pohladu na telo. Podla nich je proces myslenia spojený s našim telom najmä prostredníctvom metafory založenej na telesnej skúsenosti. Ich argumenty a vysvetlenia $\mathrm{v}$ oblasti matematického myslenia i $\mathrm{v}$ oblasti kognitívnej lingvistiky sú presvedčivé, no vyvolávajú dojem, že každá naša skúsenost' je telesná, každý abstraktný koncept našej mysle je chápaný prostredníctvom tela. Tejto myšlienke a kritike sa tak začali venovat' najmä autori z oblasti skúmania umelej inteligencie, ktorí si kládli otázku, či aj humanoidný robot (majúci rovnaké alebo podobné telo ako človek) môže spracovávat' informácie na báze rovnakých kognitívnych procesov vlastných človeku (Ziemke, 2001).

Vtelená kognícia vo svojej podstate nie je priamo zameraná na telesné aspekty ludskej mysle, hovorí prevažne o tele $\mathrm{v}$ zmysle percepčno-motorického systému, teda nepojednáva o tele ako takom. Aj napriek spomenutému je vtelená kognícia od 80-tych rokov stále pre mnohých autorov aktuálna a postupuje od teoretických štúdii $\mathrm{k}$ empirickému overovaniu hypotéz. Prínosným v tejto oblasti je jej presah do pedagogiky - zameriavanie sa autorov vtelenej kognície na oblasti matematiky (aj fyziky) a jazyka (aj čítania), ktoré sú klúčovými predmetmi vzdelávania. Jej presah do pedagogiky, celkovo do oblasti učenia (sa) upozorňuje na vnímanie mysle a myslenia ako na komplex tela (aktivity, skúsenosti), prostredia a kognície. Poukazuje na to, že aj výlučne kognitívne orientované oblasti by mali brat' do úvahy to, že učenie sa deje prostredníctvom celého tela, nie len mozgu a telesná aktivita a skúsenost' ulahčujú proces porozumenia.

\section{Literatúra}

Alibali, M. W. (2005). Gesture in spatial cognition: Expressing, comunicating, and thinking about spatial information. Spatial Cognition \& Computation, 5(4), 307-331.

Anderson, M. L. (2003). Embodied cognition: A field guide. Artificial Intelligence, 149(1), 91-103.

Arzarello, F., \& Edwards, L. (2005). Gesture and the construction of mathematical meaning. In H. L. Chick \& J. L. Vincent (Eds.), Proceedings of the 29th Conference of the International Group for the Psychology of Mathematics Education (s. 123-154). Melbourne: PME.

Audi, R. (Ed.). (1999). The Cambridge dictionary of philosophy. Cambridge: Cambridge University Press. Dostupné z http://elearning.zaou.ac.zm:8060/Philosophy-Psychology/Dictionary\% 20of\%20Philosophy\%20-\%20Cambridge\%20-\%20Robert\%20Audi\%201999.pdf 
Bautista, A., Roth, W. M., \& Thom, J. S. (2012). Knowing, insight learning, and the integrity of kinetic movement. Interchange, 42(4), 363-388.

Csordas, T. J. (1990). Embodiment as a paradigm for anthropology. Ethos, 18(1), 5-47.

Fauconnier, G., \& Turner, M. (2002). The way we think: Conceptual blending and the mind's hidden complexities. New York: Basic Books.

Fenson, L., Dale, P., Reznick, J. S., Bates, E., Thal, D. J., \& Pethick, S. J. (1994). Variability in early communicative development. Monographs of the Society for Research in Child Development, 59(5), 179-195.

Flevares, L. M., \& Perry, M. (2001). How many do you see? The use of nonspoken representations in first-grade mathematics lessons. Journal of Educational Psychology, 93(2), 330-345.

Glenberg, A. M., \& Kaschak, M. P. (2002). Grounding language in action. Psychonomic Bulletin \& Review, 9(3), 558-565.

Goldin-Meadow, S., Wagner Cook, S., \& Mitchell, Z. A. (2009). Gesturing gives children new ideas about math. Psychological Science, 20(3), 267-272.

Hostetter, A. B., \& Alibali, M. W. (2008). Visible embodiment: Gestures as simulated action. Psychonomic Bulletin \& Review, 15(3), 495-514.

Hostetter, A. B., \& Hopkins, W. D. (2002). The effect of thought structure on the production of lexical movements. Brain and Language, 82(1), 22-29.

Hutchins, E. (1995). Cognition in the wild. Cambridge, MA: MIT Press.

Cheville, J. (2005). Confronting the problem of embodiment. International Journal of Qualitative Studies in Education, 18(1), 85-107.

Kaščák, O., \& Obertová, Z. (2012). Školská etnografia tela, jej východiská, podoby a potenciály. Českýlid: Etnologický časopis, 99(1), 1-22.

Kaščák, O., \& Pupala, B. (2011). Raná výučba cudzích jazykov a jej analýza prostredníctvom etnografie tela. In M. Šucha, M. Charvát, \& V. Řehan (Eds.), Kvalitativní výzkum a vzdelávaní (s. 94-99). Olomouc: Univerzita Palackého.

Kelly, S. D. (2001). Broadening the units of analysis in communication: Speech and nonverbal behaviours in pragmatic comprehension. Journal of Child Language, 28(2), 325-349.

Kirsh, D., \& Maglio, P. (1994). On distinguishing epistemic from pragmatic action. Cognitive Science, 18(4), 513-549.

Knapp, M., \& Hall, J. (2006). Nonverbal communication in human interaction. Belmont, CA: Thomson Wadsworth.

Kováč, L. (2006). Princípy molekulárnej kognície. In J. Kelemen \& V. Kvasnička (Eds.), Kognice a umělý život VI. (s. 215-222). Opava: Slezská univerzita.

Lakoff, G., \& Johnnson, M. (1980). Metaphors we live by. Chicago: University of Chicago.

Lakoff, G., \& Johnson, M. (1999). Philosophy in the flesh: The embodied mind and its challenge to western thought. New York: Basic Books.

Lakoff, G., \& Johnson, M. (2002). Metafory, kterými žijeme. Praha: Host.

Lakoff, G., \& Nunez, R. (2000). Where mathematics comes from: How the embodied mind brings mathematics into being. New York: Basic Books.

Maouene, J., Sethurman, N., Laakso, A., \& Maouene, M. (2011). The body region correlates of concrete and abstract verbs in early child language. Cognition, Brain, Behavior. An Interdisciplinary Journal, 15(4), 449-484. 
Merleau-Ponty, M. (1966/1974). Phänomenologie der Wahrnehmung. Berlin: Walter de Gruyter. Merleau-Ponty, M. (2008). Svět vnímání. Praha: Oikoymenh.

Nunez, R., Edwards, L., \& Matos, J. F. (1999). Embodied cognition as grounding for situatedness and context in mathematics education. Educational Studies in Mathematics, 39(1-3), 45-65.

O’Regan, J. K, \& Noë, A. (2001). A sensorimotor account of vision and visual consciouness. Behavioral Brain Science, 24(5), 939-1031.

Patočka, J. (1995). Tělo, společenství, jazyk, svět. Praha: Oikoymenh.

Perry, M., Berch, D., \& Singleton, J. L. (1995). Constructing shared understanding: The role of nonverbal input in learning contexts. Journal of Contemporary Legal Issues, 6(1), 213-236.

Ping, R. M., \& Goldin-Meadow, S. (2006). Gesturing in the air: Children learn from gestures not grounded in the here-and-now. Prezentováno na konferenci Annual Meeting of the Cognitive Science Society. Dostupné z http://csjarchive.cogsci.rpi.edu/proceedings/2006/ docs/p675.pdf

Pulvermuller, F. (2005). Brain mechanisms linking language and action. Nature Reviews Neuroscience, 6(1), 576-582.

Roth, W. M. (2001). Gestures: Their role in teaching and learning. Review of Educational Research, 71(3), 365-392.

Roth, W. M. (2009). Mathematical representation at the interface of body and culture. Charlotte, NC: Information Age.

Susi, T., Lindblom, J., \& Ziemke, T. (2003). Beyond the bounds of cognition. In R. Alterman \& D. Kirsh (Eds.), Proceedings of the 25th Annual Conference of the Cognitive Science Society (s. 1134-1139). Mahwah, NJ: Lawrence Erlbaum.

Thang, N. T. (2009). Language and embodiment. Journal of Science, Foreign Languages, 20(1), 250-256.

Thom, J., \& Roth, W. M. (2011). Radical embodiment and semiotics: Toward a theory of mathematics in the flesh. Educational Studies in Mathematics, 77(1), 267-284.

Urban, P. (Ed.). (2011). Fenomenologie tělesnosti. Mimoriadne číslo filozofického časopisu. Praha: Filosofia.

Varela, F., Thompson, T., \& Rosch, E. (1991). The embodied mind: Cognitive science and human experience. Cambridge: MIT Press.

Wagner Cook, S. (2011). Abstract thinking in space and time: Using gesture to learn math. Cognition, Brain, Behavior, 15(4), 553-570.

Wagner, S. M., Nusbaum, H., \& Goldin-Meadow, S. (2004). Probing the mental representation of gesture: Is handwaving spatial? Journal of Memory \& Language, 50(4), 395-407.

Wilson, M. (2002). Six views of embodied cognition. Psychonomic Bulletin \& Review, 9(4), 625-636.

Ziemke, T. (2011). Disentangling notions of embodiment. Př́íspěvek prezentovaný na Workshop of Developmental Embodied Cognition, Edinburgh, UK. Dostupné z http://citeseerx.ist.psu. edu/.../download?

Zwaan, R. A., \& Taylor, L. J. (2006). Seeing, acting, understanding: Motor resonance in language comprehension. Journal of Experimental Psychology: General, 135(1), 1-11. 


\title{
Autorka
}

Mgr. Zuzana Obertová, Trnavská univerzita v Trnave, Pedagogická fakulta, Katedra školskej pedagogiky, Priemyselná ulica 4, 91843 Trnava, e-mail: obertova.zuzana@gmail.com

\section{Embodied cognition, its philosophical basis and its potential relevance for educational sciences}

\begin{abstract}
The purpose of this paper is to describe the theory of embodied cognition, embed it in broader philosophical framework, and induct its potential contribution to educational sciences. Text progresses from clarifying the concept of embodiment, its origins in phenomenology (M. Merleau-Ponty) and use in cultural anthropology (T. J. Csordas). In the next section, we elaborate on the philosophical framework which had an impact on the theory of embodied cognition and suppression of the dualistic view of mind and body; we clarify aspects of embodiment complementing the image of embodiment. As part of the description of the contribution of the embodied cognition to educational sciences we focus on two areas: language and mathematics, which are considered to be largely cognitive and abstract concepts separate from the body. It has been shown that the theory of embodied cognition does not sufficiently explain what the body actually is, and what kind of body is discussed here. It follows from this that in both of the areas (language and mathematics) a particularly important aspect for the process of understanding abstract systems and learning is the research on and the importance of gestures and physical experience. We found that the asset of embodied cognition for educational sciences lies in the orientation toward bodily action, activity and impact of physical environment and bodily experience on cognition, which facilitate the learning process.
\end{abstract}

Keywords: embodiment, embodied cognition, phenomenology, gestures, mathematics, language

Blížkovský, B. (2013). Celistvé a otevřené pojetí lidského učení, vzdělávání a výchovy. Sylabus základů pedagogiky. Brno: MuniPress.

Proměna škol v opravdové „dílny lidskosti“ je dle autora předkládané publikace naléhavá. Inspirací $\mathrm{k}$ nápravě je inovace základů pedagogiky, která je předložena v podobě sylabu. Publikace dále obsahuje bohatou bibliografii autora dokumentující poslední československé pedagogické konference, obnovu Pedagogické orientace v roce 1990, odborné návrhy na racionalizaci, demokratizaci a humanizaci našeho školství i další polistopadové aktivity ČPdS.

http://is.muni.cz/repo/1091235/Celistve_a_otevrene_pojeti.pdf 